\title{
52. MIDDLE MIOCENE BENTHIC FORAMINIFERAL OXYGEN AND CARBON ISOTOPES AND STRATIGRAPHY: SOUTHERN OCEAN SITE 7441
}

\author{
Fay Woodruff ${ }^{2}$ and Steven R. Chambers ${ }^{3}$
}

\begin{abstract}
We present carbon and oxygen isotope values and planktonic/benthic ratios for middle Miocene (11-17.5 Ma) foraminifers deposited at Ocean Drilling Program Hole 744B in the Southern Ocean. Major features of the isotope records are similar to those of other middle Miocene open-ocean records. The portion of the sequence containing the major middle Miocene $\delta^{18} \mathrm{O}$ increase (between 60 and $52 \mathrm{~m}$ below seafloor) is a relatively condensed zone characterized by low planktonic/benthic ratios and several hiatuses.

The isotopic record is of sufficiently high resolution to date the $\delta^{18} \mathrm{O}$ minima and the $\delta^{13} \mathrm{C}$ maxima to within 200,000 yr. Ages determined using the oxygen and carbon isotope stratigraphy are similar to those obtained using diatom, radiolarian, and paleomagnetic stratigraphy, but are approximately 1 m.y. younger than those determined using the strontium isotope stratigraphy published in this volume.

The average middle Miocene sediment-accumulation rate for Hole $744 \mathrm{~B}$ is approximately $4 \mathrm{~m} / \mathrm{m} . \mathrm{y}$.
\end{abstract}

\section{INTRODUCTION}

Ocean Drilling Program (ODP) Site 744 is located in the Southern Ocean at $61^{\circ} 34^{\prime} \mathrm{S}, 80^{\circ} 35^{\prime} \mathrm{E}$ on the southern Kerguelen Plateau. The modern water depth at Site 744 is $2307 \mathrm{~m}$. Using data from the preliminary reports for ODP Leg 119 (Barron, Larsen, et al., 1989), the backtracked middle Miocene water depth was approximately $2150 \mathrm{~m}$, making this the deepest site in the Southern ocean for which middle Miocene isotopic data are available.

\section{ISOTOPIC METHODS AND PROCEDURES}

Benthic foraminifer samples were analyzed at the Stable Isotope Laboratory, University of Michigan. All calcite samples were roasted at $380^{\circ} \mathrm{C}$ to remove volatile contaminants. Samples ranging in weight from 100 to $300 \mu \mathrm{g}$ were individually reacted at $73^{\circ} \mathrm{C}$ with 4 drops of anhydrous phosphoric acid in a Finnigan MAT carbonate extraction system ("Keil" device) coupled directly to the inlet of a Finnigan MAT 251 isotope ratio mass spectrometer. Isotopic enrichments were corrected for acid fractionation and ${ }^{17} \mathrm{O}$ contribution. Data are reported in the standard delta $(\delta)$ notation representing the per mil deviation of the sample from the Peedee Belemnite (PDB) standard. Precision and calibration of data were monitored through daily analysis of NBS- 20 powdered carbonate, which bracketed sample analyses. The measured analytical precision was better than $0.1 \%$ for both carbon and oxygen isotope analyses.

The oxygen and carbon isotopic values for benthic foraminifers at Hole 744B are listed in Table 1 and shown in Figures 1 and 2. We only use the tests of Cibicidoides species because modern species of this genus live at or above the sediment/water interface and should, therefore, record the physical and chemical states of ocean bottom waters (Lutze and Thiel, 1987).

\footnotetext{
${ }^{1}$ Barron, J., Larsen, B., et al., 1991. Proc. ODP, Sci. Results, 119: College Station, TX (Ocean Drilling Program).

2 Geological Sciences, University of Southern California, Los Angeles, CA 90089-0740, U.S.A.

${ }^{3}$ Department of Geology, Stanford, CA 94035, U.S.A.
}

\section{RESULTS AND DISCUSSION}

\section{Carbonate Preservation}

The preservation state of middle Miocene foraminifers at Site 744 is fair. The benthic foraminifers are etched and have a milky luster. Many of the less robust species have been removed by dissolution. The planktonic foraminifers are highly fragmented. Middle Miocene planktonic/benthic ratios are low at Site 744, ranging from less than $1: 1$ to $971: 1$ and averaging $80: 1$ (Table 1). These values are particularly low when compared to other middle Miocene Indian Ocean sites closer to the equator. Average planktonic/benthic ratios are 320:1 at Hole 709B (backtracked water depth $2.8 \mathrm{~km}$, located $4^{\circ} \mathrm{S}, 6^{\circ} \mathrm{E}$ ) and are $1400: 1$ at Site 237 (backtracked water depth $1.4 \mathrm{~km}$, located at $7^{\circ} \mathrm{S}, 58^{\circ} \mathrm{E}$; Woodruff et al., in press). The calcium carbonate contents of sediments representing this period at Site 744 are low, ranging from $60.7 \%$ to $80.6 \%$ (Barron, Larsen, et al., 1989). The sediment-accumulation rates for middle Miocene time are also low and are calculated to be $3.7 \mathrm{~m} / \mathrm{m}$.y using isotopic stratigraphy.

\section{Stratigraphy}

The core depth of the middle Miocene stratigraphic ages assigned at Hole 744B are listed in Table 2 and are shown in Figure 2 . Figure 2 shows the $\delta^{13} \mathrm{C}$ isotopic record superimposed on the $\delta^{18} \mathrm{O}$ record with the isotopic scales reversed (i.e., low $\delta^{18} \mathrm{O}$ values are scaled with high $\delta^{13} \mathrm{C}$ values). The six " $\delta^{13} \mathrm{C}$ maxima" of the Monterey Excursion are shown by large numbers and the " $\delta^{18} \mathrm{O}$ events" are shown by large letters with the age interpretation of Woodruff and Savin (in press) below. Biostratigraphic age datums from the stratigraphic synthesis of Barron et al. (this volume) are shown as triangles below the isotopic curves for comparison with the " $\delta^{18} \mathrm{O}$ event" stratigraphy. The stratigraphic ages assigned to the oxygen and carbon isotope data are based on the correlation of detailed isotopic records from six sites in the Pacific and Indian oceans with the biostratigraphies of radiolarians, nannofossils, diatoms, and planktonic foraminifers by many authors (Woodruff and Savin, 1989; Woodruff and Savin, in press). The other stratigraphies are as follows: diatoms (Baldauf and Barron, this volume), radiolarians (Lazarus, in press), strontium isotopes (Barrera et al., this volume), and paleomagnetic stratigraphy (Barron et al., this volume; Keating, this volume). 
Table 1. Benthic foraminifer (Cibicidoides) $\delta^{18} \mathrm{O}$ and $\delta^{13} \mathrm{C}$ values and planktonic to benthic foraminifer ratios for Hole 744B.

\begin{tabular}{|c|c|c|c|c|c|c|}
\hline $\begin{array}{l}\text { Core, section, } \\
\text { interval }(\mathrm{cm})\end{array}$ & $\begin{array}{l}\text { Depth } \\
\text { (mbsf) }\end{array}$ & Species & $\begin{array}{c}\delta^{18} \mathrm{O} \\
(\%, \mathrm{PDB})\end{array}$ & $\begin{array}{c}\delta^{13} \mathrm{C} \\
(\%, \mathrm{PDB})\end{array}$ & $\begin{array}{c}\text { Planktonic/ } \\
\text { benthic } \\
\text { ratios }\end{array}$ & $\begin{array}{c}\text { Sample } \\
\text { size } \\
\left(\mathrm{cm}^{3}\right)\end{array}$ \\
\hline $5 \mathrm{H}-1,105-107$ & 32.05 & Cibicidoides sp. B & ${ }^{\mathrm{a}}$ Lost & Lost & 1 & 10 \\
\hline $5 \mathrm{H}-2,93-95$ & 33.43 & Cibicidoides kullenbergi and sp. B & Lost & Lost & 1 & 10 \\
\hline $5 \mathrm{H}-3,105-107$ & 35.05 & Rare & Not sent & Not sent & 641 & 10 \\
\hline $5 \mathrm{H}-4,105-107$ & 36.55 & Cibicidoides kullenbergi and sp. B & Lost & Lost & 64 & 10 \\
\hline $5 \mathrm{H}-5,105-107$ & 38.05 & Cibicidoides kullenbergi and sp. B & 2.37 & 1.00 & 5 & 10 \\
\hline $5 \mathrm{H}-6,105-107$ & 39.55 & Cibicidoides kullenbergi and sp. B & Lost & Lost & 1 & 10 \\
\hline $6 \mathrm{H}-1,105-106$ & 41.55 & Cibicidoides kullenbergi and sp. B & Lost & Lost & 19 & 10 \\
\hline $6 \mathrm{H}-2,105-107$ & 43.05 & Cibicidoides sp. B & Lost & Lost & 21 & 10 \\
\hline $6 \mathrm{H}-3,105-107$ & 44.55 & Cibicidoides sp. B & Lost & Lost & 26 & 10 \\
\hline $6 \mathrm{H}-4,105-107$ & 46.05 & Cibicidoides sp. B & Lost & Lost & 7 & 10 \\
\hline $6 \mathrm{H}-5,105-107$ & 47.55 & Cibicidoides sp. B & Lost & Lost & 57 & 10 \\
\hline $6 \mathrm{H}-6,105-107$ & 49.05 & Cibicidoides sp. B & Not sent & Not sent & 24 & 10 \\
\hline $7 \mathrm{H}-1,23-28$ & 50.23 & Cibicidoides sp. B & 2.57 & 1.24 & 188 & 25 \\
\hline $7 \mathrm{H}-1,74-79$ & 50.74 & Cibicidoides sp. B & 2.73 & 1.21 & 361 & 25 \\
\hline $7 \mathrm{H}-1,105-110$ & 51.05 & Cibicidoides sp. B & 2.41 & 1.15 & 127 & 10 \\
\hline $7 \mathrm{H}-1,120-125$ & 51.20 & Cibicidoides kullenbergi & 2.33 & 0.88 & $b_{n \cdot d .}$ & 10 \\
\hline $7 \mathrm{H}-2,23-28$ & 51.73 & Cibicidoides sp. B & Too small & Too small & 22 & 25 \\
\hline $7 \mathrm{H}-2,74-79$ & 52.24 & Cibicidoides sp. B & 2.54 & 1.56 & 58 & 25 \\
\hline $7 \mathrm{H}-2,105-110$ & 52.55 & Cibicidoides kullenbergi and sp. B & 3.37 & 1.66 & 971 & 10 \\
\hline $7 \mathrm{H}-2,120-125$ & 52.70 & Cibicidoides sp. B & 2.57 & 1.29 & n.d. & 10 \\
\hline $7 \mathrm{H}-3,23-28$ & 53.23 & Cibicidoides kullenbergi and sp. B & 2.29 & 1.12 & 26 & 25 \\
\hline $7 \mathrm{H}-3,74-79$ & 53.74 & Cibicidoides kullenbergi & 2.27 & 0.94 & 2 & 25 \\
\hline $7 \mathrm{H}-3,105-110$ & 54.05 & Cibicidoides kullenbergi and wuellerstorfi & Lost & Lost & 61 & 10 \\
\hline $7 \mathrm{H}-4,23-28$ & 54.73 & Cibicidoides wuellerstorfi and kullenbergi & 2.30 & 1.38 & n.d. & 25 \\
\hline $7 \mathrm{H}-4,74-77$ & 55.24 & Cibicidoides wuellerstorfi & 1.75 & 1.76 & 29 & 25 \\
\hline $7 \mathrm{H}-4,105-110$ & 55.55 & Cibicidoides kullenbergi & 1.89 & 1.43 & 7 & 10 \\
\hline $7 \mathrm{H}-5,24-29$ & 56.24 & Ciicidoides wuellerstorfi and kullenbergi & 1.75 & 1.78 & 20 & 10 \\
\hline $7 \mathrm{H}-5,74-79$ & 56.74 & Cibicidoides kullenbergi and wuellerstorfi & 1.65 & 1.52 & 29 & 25 \\
\hline $7 \mathrm{H}-5,105-110$ & 57.05 & Cibicidoides kullenbergi and wuellerstorfi & 1.76 & 1.61 & 21 & 10 \\
\hline $7 \mathrm{H}-6,25-30$ & 57.75 & Cibicidoides kullenbergi & 1.59 & 1.82 & 1 & 25 \\
\hline $7 \mathrm{H}-6,25-30$ & 57.75 & Cibicidoides kullenbergi & 0.37 & 1.38 & 1 & 25 \\
\hline $7 \mathrm{H}-6,25-30$ & 57.75 & Cibicidoides wuellerstorfi & 1.91 & 1.88 & 1 & 25 \\
\hline $7 \mathrm{H}-6,25-30$ & 57.75 & Cibicidoides wuellerstorfi & 1.40 & 1.73 & 1 & 25 \\
\hline $7 \mathrm{H}-6,74-79$ & 58.24 & Cibicidoides kullenbergi and wuellerstorfi & 1.43 & 1.48 & 1 & 25 \\
\hline $7 \mathrm{H}-6,105-110$ & 58.55 & Cibicidoides kullenbergi and wuellerstorfi & 1.52 & 1.55 & n.d. & 10 \\
\hline $7 \mathrm{H}-6,120-125$ & 58.70 & Cibicidoides kullenbergi and wuellerstorfi & 1.95 & 1.38 & n.d. & 10 \\
\hline $7 \mathrm{H}-7,23-28$ & 9.23 & Cibicidoides kullenbergi & 1.71 & 1.46 & 10 & 25 \\
\hline $7 \mathrm{H}-7,72-76$ & 59.72 & Cibicidoides kullenbergi and wuellerstorfi & 1.39 & 1.73 & 11 & 25 \\
\hline $8 \mathrm{H}-1,24-29$ & 59.74 & Cibicidoides kullenbergi & 1.29 & 1.39 & 11 & 25 \\
\hline $8 \mathrm{H}-1,74-79$ & 60.24 & Cibicidoides kullenbergi & 1.27 & 1.82 & 272 & 25 \\
\hline
\end{tabular}

The isotopic ages assigned to the events in the oxygen and carbon isotopic curves are in close agreement with those indicated by diatom, radiolarian, and paleomagnetic stratigraphy. However, the strontium isotope dates are generally at least 1 m.y. older. The paleomagnetic stratigraphy tends to give slightly older ages than the oxygen and carbon isotope stratigraphy in the earliest middle Miocene portion of the record. Although the age of each particular paleomagnetic reversal has been dated by geochronologic methods, the identification of each reversal in a sedimentary section is performed by the biostratigrapher. The relatively old strontium isotopes ages are probably a result of the fact that the early middle Miocene strontium isotope record has only been correlated to microfossil stratigraphy at one site (Site 590) where there is disagreement between the foraminiferal and the nannofossil biostratigraphies. Furthermore, the isotopic record at Site 590 (Kennett, 1986) suggests that there is a large hiatus or condensed zone in the sedimentary record at the interval in question.

\section{Hiatuses}

Hiatuses, low planktonic/benthic ratios, and condensed sections are often associated in the sedimentary record. The core depths of hiatuses and intense dissolution intervals (low planktonic/benthic ratios) identified in the sedimentary record of Hole 744B are shown in Table 2. Several of the intervals of intense dissolution discovered at Hole 744B are correlated with the Neogene hiatus (NH) scheme constructed by Keller and Bar- ron (1983). The presence of hiatuses interpreted from the oxygen and carbon isotopic record (NH3A at $55 \mathrm{~m}$ below seafloor (mbsf) and NH3B at $53 \mathrm{mbsf}$ ) and the diatom record (Baldauf and Barron, this volume) may explain the spread of age determinations in the diatom and radiolarian records $(11.9,12.3$, 12.45, and $13.4 \mathrm{Ma}$ ) for the interval between 52.2 and 55.23 mbsf (Table 2). At Site 744, middle Miocene intervals with low calcium carbonate contents correlate well with intervals of low planktonic/benthic ratios. The dissolution interval (55-53 mbsf) containing hiatuses $\mathrm{NH} 3 \mathrm{~A}$ and $\mathrm{NH} 3 \mathrm{~B}$ has particularly low calcium carbonate abundances for this site $(64 \%-78 \%$; Dorn, this volume). Planktonic/benthic ratios are generally better indicators of intense dissolution than carbonate contents because a severely dissolved interval can still have high calcium carbonate abundances. The lowest planktonic/benthic ratios within this interval (2:1) are found at $53.7 \mathrm{mbsf}$. The designation of NH2B at 59.23-57.75 mbsf is suggested by the isotopic record, the particularly low planktonic/benthic ratios $(1: 1$ to $10: 1)$ and the particularly low carbonate abundances $(51 \%-85 \%$; Dorn, this volume). Hiatus NH2A was not recognized in the isotopic record but the low planktonic/benthic ratios (2:1 to $27: 1)$ and the low calcium carbonate abundances $(40 \%-78 \%$; Dorn, this volume) suggest a dissolution interval at $65.96-63.44$ mbsf.

\section{Stable Isotope Data}

The middle Miocene oxygen and carbon isotopic curves for Hole 744B (Figs. 1 and 2) show similar trends to those described 
Table 1 (continued).

\begin{tabular}{|c|c|c|c|c|c|c|}
\hline $\begin{array}{l}\text { Core, section, } \\
\text { interval }(\mathrm{cm})\end{array}$ & $\begin{array}{l}\text { Depth } \\
\text { (mbsf) }\end{array}$ & Species & $\begin{array}{c}\delta^{18} \mathrm{O} \\
\left(\%_{0}, \mathrm{PDB}\right)\end{array}$ & $\begin{array}{c}\delta^{13} \mathrm{C} \\
(\% 0, \mathrm{PDB})\end{array}$ & $\begin{array}{c}\text { Planktonic/ } \\
\text { benthic } \\
\text { ratios }\end{array}$ & $\begin{array}{c}\text { Sample } \\
\text { size } \\
\left(\mathrm{cm}^{3}\right)\end{array}$ \\
\hline $8 \mathrm{H}-1,74-79$ & 60.24 & Cibicidoides kullenbergi & 1.21 & 1.49 & 272 & 25 \\
\hline $8 \mathrm{H}-1,105-107$ & 60.55 & Cibicidoides kullenbergi & 1.87 & 1.82 & 108 & 10 \\
\hline $8 \mathrm{H}-2,24-29$ & 61.24 & Cibicidoides kullenbergi & 1.61 & 1.70 & 119 & 25 \\
\hline $8 \mathrm{H}-2,74-79$ & 61.74 & Cibicidoides kullenbergi & 1.41 & 1.66 & 244 & 25 \\
\hline $8 \mathrm{H}-2,105-107$ & 62.05 & Cibicidoides spp. & 2.09 & 1.84 & 85 & 10 \\
\hline $8 \mathrm{H}-3,24-29$ & 62.75 & Cibicidoides kullenbergi & 1.78 & 1.80 & 38 & 25 \\
\hline $8 \mathrm{H}-3,74-77$ & 63.24 & Cibicidoides kullenbergi & Too small & Too small & 128 & 25 \\
\hline $8 \mathrm{H}-3,105-107$ & 63.55 & Cibicidoides kullenbergi and wuellerstorfi & 1.07 & 1.39 & 20 & 10 \\
\hline $8 \mathrm{H}-4,24-29$ & 64.24 & Cibicidoides kullenbergi & 1.74 & 1.83 & 22 & 25 \\
\hline $8 \mathrm{H}-4,74-79$ & 64.74 & Cibicidoides kullenbergi & 1.93 & 1.90 & 27 & 25 \\
\hline $8 \mathrm{H}-4,74-79$ & 64.74 & Cibicidoides kullenbergi & 1.86 & 1.91 & 27 & 25 \\
\hline $8 \mathrm{H}-4,105-107$ & 65.05 & Cibicidoides kullenbergi & 1.78 & 2.10 & 2 & 10 \\
\hline $8 \mathrm{H}-5,24-27$ & 65.74 & Cibicidoides kullenbergi & 1.14 & 1.45 & 75 & 25 \\
\hline $8 \mathrm{H}-5,69-74$ & 66.19 & Cibicidoides kullenbergi & 1.46 & 1.79 & 122 & 25 \\
\hline $8 \mathrm{H}-5,105-107$ & 66.55 & Cibicidoides kullenbergi & 1.42 & 1.72 & 105 & 10 \\
\hline $8 \mathrm{H}-6,24-27$ & 67.24 & Cibicidoides kullenbergi & 1.55 & 1.59 & 13 & 25 \\
\hline $8 \mathrm{H}-6,70-75$ & 67.70 & Cibicidoides kullenbergi & 1.27 & 1.52 & 2 & 25 \\
\hline $8 \mathrm{H}-6,105-107$ & 68.05 & Cibicidoides kullenbergi & Lost & Lost & 10 & 10 \\
\hline $8 \mathrm{H}-7,24-29$ & 68.74 & Cibicidoides kullenbergi & 0.72 & 1.29 & 27 & 25 \\
\hline $9 \mathrm{H}-1,24-29$ & 69.24 & Cibicidoides kullenbergi & 1.51 & 1.29 & 65 & 25 \\
\hline $9 \mathrm{H}-1,74-79$ & 69.74 & Cibicidoides kullenbergi & 1.64 & 1.56 & 16 & 25 \\
\hline $9 \mathrm{H}-1,125-130$ & 70.25 & Cibicidoides kullenbergi & 2.04 & 1.59 & n.d. & 10 \\
\hline $9 \mathrm{H}-2,24-29$ & 70.74 & Cibicidoides kullenbergi & Lost & Lost & 2 & 25 \\
\hline $9 \mathrm{H}-2,77-81$ & 71.27 & Cibicidoides kullenbergi & Lost & Lost & 1 & 25 \\
\hline $9 \mathrm{H}-2,125-130$ & 71.75 & Cibicidoides kullenbergi & 1.79 & 1.47 & n.d. & 10 \\
\hline $9 H-3,24-29$ & 72.24 & Cibicidoides kullenbergi & 1.93 & 1.47 & 6 & 25 \\
\hline $9 \mathrm{H}-3,74-79$ & 72.74 & Cibicidoides kullenbergi & 1.75 & 1.44 & 46 & 25 \\
\hline $9 \mathrm{H}-3,74-79$ & 72.74 & Cibicidoides kullenbergi & Lost & Lost & 46 & 25 \\
\hline $9 \mathrm{H}-3,125-130$ & 73.25 & Cibicidoides kullenbergi & 1.87 & 1.52 & n.d. & 10 \\
\hline $9 \mathrm{H}-4,24-29$ & 73.74 & Cibicidoides kullenbergi & Lost & Lost & 33 & 25 \\
\hline $9 \mathrm{H}-4,74-79$ & 74.24 & Cibicidoides kullenbergi & 1.82 & 1.51 & 15 & 25 \\
\hline $9 \mathrm{H}-4,125-130$ & 74.75 & Cibicidoides kullenbergi & 2.05 & 1.56 & n.d. & 10 \\
\hline $9 \mathrm{H}-5,28-33$ & 75.28 & Cibicidoides kullenbergi & Lost & Lost & 29 & 25 \\
\hline $9 \mathrm{H}-5,28-33$ & 75.28 & Cibicidoides kullenbergi & 1.96 & 1.52 & 29 & 25 \\
\hline $9 \mathrm{H}-5,78-83$ & 75.78 & Cibicidoides kullenbergi & 1.59 & 1.30 & 73 & 25 \\
\hline $9 \mathrm{H}-5,78-83$ & 75.78 & Cibicidoides kullenbergi & Lost & Lost & 73 & 25 \\
\hline $9 \mathrm{H}-5,125-130$ & 76.25 & Cibicidoides kullenbergi & 1.76 & 1.20 & n.d. & 10 \\
\hline $9 \mathrm{H}-6,23-28$ & 76.73 & Cibicidoides kullenbergi & 2.05 & 1.46 & 422 & 25 \\
\hline $9 \mathrm{H}-6,23-28$ & 76.73 & Cibicidoides kullenbergi & Lost & Lost & 422 & 25 \\
\hline $9 \mathrm{H}-6,74-79$ & 77.24 & Cibicidoides kullenbergi & 1.69 & 1.12 & 123 & 25 \\
\hline $9 \mathrm{H}-6,74-79$ & 77.24 & Cibicidoides kullenbergi & 1.60 & 1.04 & 123 & 25 \\
\hline $9 \mathrm{H}-6,125-126$ & 77.75 & Cibicidoides kullenbergi & 1.74 & 1.20 & n.d. & 10 \\
\hline
\end{tabular}

a "Lost" refers to data lost as a result of a computer failure during mass spectrometric analysis.

b.d. = not determined.

A

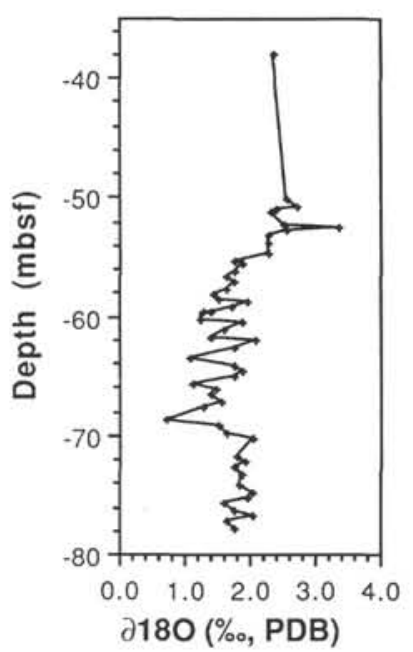

B

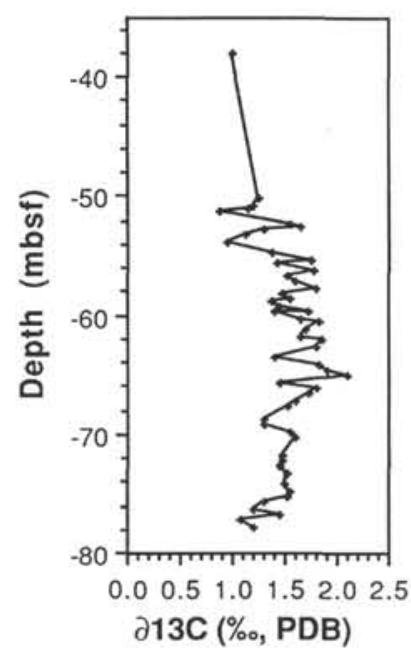

Figure 1. Plots of (A) $\delta^{18} \mathrm{O}$ and (B) $\delta^{13} \mathrm{C}$ values of benthic foraminifers (Cibicidoides) vs. depth below the seafloor at ODP Hole 744B.

for many other sites in the world ocean. Between 58 and 69 mbsf (approximately 14.3-16.6 Ma) foraminifer oxygen isotope ratios vary considerably but average +1.5 . The $1 \%$ increase in foraminifer $\delta^{18} \mathrm{O}$ values that has been identified in middle Miocene sections throughout the world ocean was also observed at Site 744. This major isotopic "event" begins at $60 \mathrm{mbsf}$ in Hole $744 \mathrm{~B}$ and continues to $50 \mathrm{mbsf}$, where $\delta^{18} \mathrm{O}$ values exceed $+2.5 \%$.

The carbon isotope curve for Site 744 exhibits the period of exceptionally high $\delta^{13} \mathrm{C}$ values commonly referred to as the Monterey Excursion (Figs. 1B and 2; Vincent and Berger, 1985). The period begins with a $0.5 \%$ increase in $\delta^{13} \mathrm{C}$ near $17 \mathrm{Ma}$ (approximately $67 \mathrm{mbsf}$ in Hole 744B) to values greater than $1.6 \%$. It continues with exceptionally high values, which average $1.65 \%$. The end of the Monterey Excursion is signaled by a $0.5 \%$ decrease in $\delta^{13} \mathrm{C}$ values after $14 \mathrm{Ma}$ (approximately $55 \mathrm{mbsf}$ in Hole 744B).

Compared to other open-ocean middle Miocene records, the $\delta^{13} \mathrm{C}$ values between 55.50 and $59.23 \mathrm{mbsf}$ in Hole 744B are unexpectedly irregular. These values fall within an intense dissolution zone found between 53 and 59 mbsf as shown by the very low planktonic/benthic ratios (average 17:1) and the low abundance of calcium carbonate $(60 \%-85 \%$; Dorn, this volume). The $\delta^{13} \mathrm{C}$ values therefore may reflect disturbances often associated with dissolution such as multiple slumps and turbidites (Woodruff and Savin, in press). 


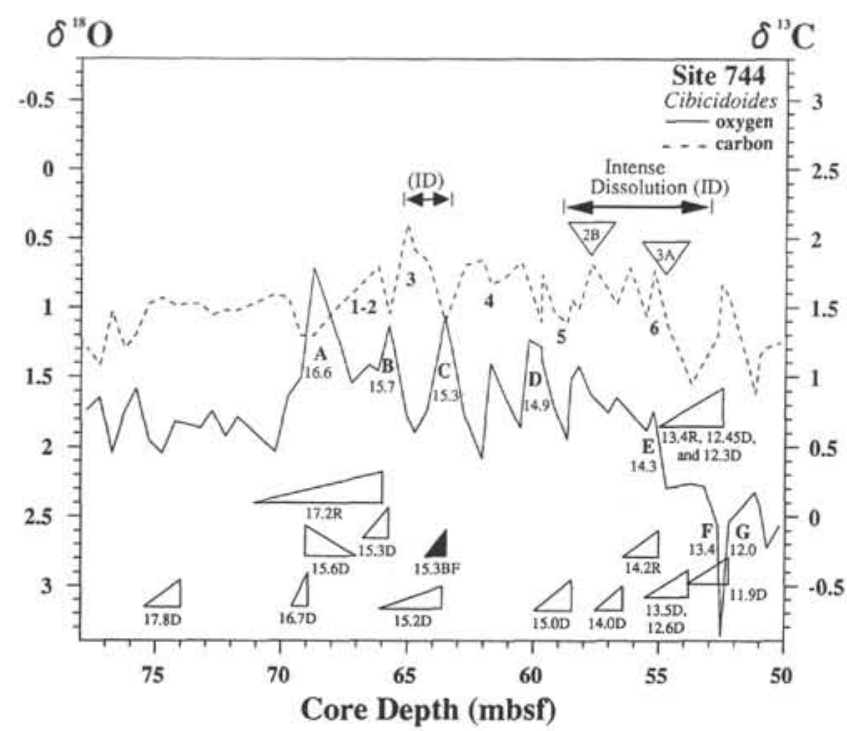

Figure 2. $\delta^{18} \mathrm{O}$ and $\delta^{13} \mathrm{C}$ isotope curves of Cibicidoides species vs. depth below seafloor for ODP Hole 744B. Note the difference in isotope scales. The letters beneath the $\delta^{13} \mathrm{C}$ curve show the seven "18 $\mathrm{O}$ events" and their ages determined by Woodruff and Savin (in press) for the period of the Monterey Excursion. The triangles below the isotope curves show core depth of the top or bottom of each biostratigraphic range and the depth of uncertainty between the samples studied (from Barron et al., this volume). Below each triangle is the age (Ma) of the datum and a letter identifying its fossil group (diatom or radiolarian). The triangles above the isotopic curve show the location of hiatuses (see Table 2).

The isotope record suggests that there is a previously unidentified hiatus of approximately $400 \mathrm{k} . \mathrm{y}$. somewhere within the interval 66-68 mbsf, based on the stable isotope stratigraphy developed by Woodruff and Savin (in press), perhaps associated with the extremely low planktonic/benthic ratios $(<13: 1)$ and low calcium carbonate abundance data $(72 \%-79 \%$; Dorn, this volume) between 68.1 and $67.0 \mathrm{mbsf}$. The periods of exceptionally high $\delta^{13} \mathrm{C}$ values $(>1.5)$ appear to be relatively less condensed than the intervening periods that are characterized by low $\delta^{18} \mathrm{O}$ values $(<1.4 \%$ ) when compared to high-resolution isotopic records in the equatorial Pacific Ocean (Woodruff and Savin, in press).

\section{ACKNOWLEDGMENTS}

We wish to thank Alex Carlos for his help with sample preparation in the Micropaleontology Laboratory at the University of Southern California; Kevin Given, Jim Burdett, and Jim $O$ 'Neil for performing the stable isotope analyses in the Stable Isotope Laboratory at the University of Michigan, Ann Arbor; and John Barron for many helpful discussions. This work was supported by NSF grant OCE-8800449 to F.W. and JOI USSAC grant 20216 to S.R.C.

\section{REFERENCES}

Barron, J., Larsen, B., et al., 1989. Proc. ODP, Init. Repts., 119: College Station, TX (Ocean Drilling Program), 282, 477-504.

Keller, G., and Barron, J. A., 1983. Paleoceanographic implications of Miocene deep sea hiatuses. Geol. Soc. Am. Bull., 94:590-613.

Kennett, J. P., 1986. Miocene to early Pliocene oxygen and carbon isotope stratigraphy in the southwest Pacific, Deep Sea Drilling Project Leg 90. In Kennett, J. P., von der Borch, C. C., et al., Init. Repts. DSDP, 90, Pt. 2: Washington (U.S. Govt. Printing Office), 13831411.

Lazarus, D., in press. Antarctic Neogene radiolarians from the Kerguelen Plateau, ODP Legs 119 and 120. In Schlich, R., Wise, S. W., et al., Proc. ODP, Sci. Results, 120: College Station, TX (Ocean Drilling Program).

Lutze, G. F., and Thiel, H., 1987. Cibicidoides wuellerstorfi and Planulina ariminensis, elevated epibenthic foraminifera. Ber. Sonderforschungsbereich, 313:17-30.

Vincent, E., and Berger, W. H., 1985. Carbon dioxide and polar cooling in the Miocene: the Monterey hypothesis. In Sundquist, E. T., and Broecker, W. S. (Eds.), The Carbon Cycle and Atmospheric $\mathrm{CO}_{2}$. Natural Variations Archean to Present. Am. Geophys. Union, Geophys. Monograph Series, 32:455-468.

Woodruff, F., and Savin, S. M., 1989. Miocene deepwater oceanography. Paleoceanography, 4:87-140.

in press. Mid-Miocene isotope stratigraphy in the deep-sea: high resolution correlations, paleoclimatic cycles, and sediment preservation. Paleoceanography.

Woodruff, F., Savin, S. M., and Abel, L., in press. Miocene Indian Ocean benthic foraminiferal oxygen and carbon isotopes: ODP Site 709. In Backman, J., Duncan, R., et al., Proc. ODP, Sci. Results, 115: College Station, TX (Ocean Drilling Program).

Date of initial receipt: 11 February 1990

Date of acceptance: 19 July 1990

Ms 119B-209 
Table 2. Stratigraphy and dissolution intervals for ODP Hole 744B.

\begin{tabular}{|c|c|c|c|c|c|}
\hline $\begin{array}{l}\text { Depth } \\
\text { (mbsf) }\end{array}$ & $\begin{array}{c}\text { Oxygen } \\
\text { isotope } \\
\text { stratigraphy }^{\mathrm{a}}\end{array}$ & $\begin{array}{c}\text { Planktonic/ } \\
\text { benthic ratios } \\
<10: 1\end{array}$ & $\begin{array}{l}\text { Planktonic } \\
\text { datums }{ }^{b, c}\end{array}$ & $\begin{array}{l}\text { Strontium } \\
\text { isotopes }\end{array}$ & $\begin{array}{l}\text { Paleomagnetic } \\
\text { ages }^{b, e}\end{array}$ \\
\hline $50.0-50.7$ & & & $10.9 \mathrm{Ma}(\mathrm{D})$ & & \\
\hline $50.4-51.39$ & & & & & $\begin{array}{c}11.03 \mathrm{Ma} \\
\text { (C5N-3 top) }\end{array}$ \\
\hline $51.39-52.05$ & & & & & $\begin{array}{c}11.09 \mathrm{Ma} \\
\text { (C5N-3 base) }\end{array}$ \\
\hline 52.0 & $12.0 \mathrm{Ma}\left({ }^{18} \mathrm{O}, \mathrm{G}\right)$ & & & & \\
\hline $52.2-53.7$ & & & $11.9 \mathrm{Ma}$ (D) & & \\
\hline $52.65-55.23$ & 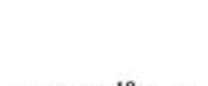 & & $\begin{array}{c}12.3 \mathrm{Ma}(\mathrm{D}), \\
12.45 \mathrm{Ma}(\mathrm{D}), \\
13.4 \mathrm{Ma}(\mathrm{R})\end{array}$ & & \\
\hline 52.7 & $13.4 \mathrm{Ma}\left({ }^{18} \mathrm{O}, \mathrm{F}\right)$ & & & & \\
\hline 53.0 & hiatus $\mathrm{NH} 3 \mathrm{~B}$ & & hiatus & & \\
\hline 53.74 & & $\begin{array}{l}\text { intense } \\
\text { dissolution }\end{array}$ & & & \\
\hline $53.70-55.20$ & & & $\begin{array}{l}12.6 \mathrm{Ma} \text { (D), } \\
13.5 \mathrm{Ma} \text { (D) }\end{array}$ & & \\
\hline $54.5-55.2$ & & & hiatus & & \\
\hline $54.73-55.24$ & hiatus NH3A & & & & \\
\hline $54.91-55.38$ & & & & & $\begin{array}{c}13.69 \mathrm{Ma} \\
\text { (C5AN-7 top) }\end{array}$ \\
\hline $\begin{array}{c}55.23-56.73 \\
55.24\end{array}$ & $14.3 \mathrm{Ma}\left({ }^{18} \mathrm{O}, \mathrm{E}\right)$ & & 14.2 Ma (R) & & \\
\hline 55.55 & & $\begin{array}{c}\text { intense } \\
\text { dissolution }\end{array}$ & & & \\
\hline $56.7-58.2$ & & & $14.0 \mathrm{Ma}(\mathrm{D})$ & 15.9 & \\
\hline $57.75-59.23$ & hiatus NH2B & $\begin{array}{l}\text { intense } \\
\text { dissolution }\end{array}$ & & & \\
\hline $58.14-59.22$ & & & & & $\begin{array}{c}14.66 \mathrm{Ma} \\
\text { (C5AN-8 base) }\end{array}$ \\
\hline 59.71 & & & & $15.9 \mathrm{Ma}$ & \\
\hline $59.75-60.38$ & & & & & $\begin{array}{c}14.87 \mathrm{Ma} \\
\text { (C5BN-1 top) }\end{array}$ \\
\hline 60.1 & $14.9 \mathrm{Ma}\left({ }^{18} \mathrm{O}, \mathrm{D}\right)$ & & & & \\
\hline 60.11 & & & & $15.9 \mathrm{Ma}$ & \\
\hline $60.91-61.81$ & & & & & $\begin{array}{c}15.27 \mathrm{Ma} \\
\text { (C5BN-2 base) }\end{array}$ \\
\hline $60.1-61.6$ & & & $15.0 \mathrm{Ma}(\mathrm{D})$ & & \\
\hline 63.11 & & & & $16.1 \mathrm{Ma}$ & \\
\hline 63.55 & $15.3 \mathrm{Ma}\left({ }^{18} \mathrm{O}, \mathrm{C}\right)$ & & & & \\
\hline 64.6-66.1 & & & $15.2 \mathrm{Ma}$ (D) & & \\
\hline $64.84-65.37$ & & & & $16.22 \mathrm{Ma}$ & (C5CN-1 top) \\
\hline 65.05 & & $\begin{array}{l}\text { intense } \\
\text { dissolution }\end{array}$ & & & \\
\hline 65.8 & $15.7 \mathrm{Ma}\left({ }^{18} \mathrm{O}, \mathrm{B}\right)$ & & & & \\
\hline $66.1-67.6$ & & & $\begin{array}{l}15.3 \mathrm{Ma} \text { (D), } \\
15.6 \mathrm{Ma} \text { (D) }\end{array}$ & & \\
\hline 66.11 & & & & $17.0 \mathrm{Ma}$ & \\
\hline $66.23-71.3$ & & & 17.2(?) $\mathrm{Ma}(\mathrm{R})$ & & \\
\hline $66.85-66.95$ & & & & & $\begin{array}{c}16.98 \mathrm{Ma} \\
\text { (C5CN-3 base) }\end{array}$ \\
\hline 67.7 & & $\begin{array}{l}\text { intense } \\
\text { dissolution }\end{array}$ & & & \\
\hline 68.8 & $16.6 \mathrm{Ma}\left({ }^{18} \mathrm{O}, \mathrm{A}\right)$ & & & & \\
\hline $69.0-69.58$ & & & $\begin{array}{l}16.0 \mathrm{Ma} \text { (D), } \\
16.7 \mathrm{Ma} \text { (D) }\end{array}$ & & \\
\hline 69.59 & & & & $17.6 \mathrm{Ma}$ & \\
\hline $70.74-72.24$ & & $\begin{array}{l}\text { intense } \\
\text { dissolution }\end{array}$ & & & \\
\hline $71.3-80.73$ & & & $17.2-18.4 \mathrm{Ma}(\mathrm{R})$ & & \\
\hline $71.6-72.4$ & & & & & $\begin{array}{c}17.57 \mathrm{Ma} \\
\text { (C5DN-1 top) }\end{array}$ \\
\hline 74.09 & & & & $18.03 \mathrm{Ma}$ & \\
\hline $75.25-75.76$ & & & & & $\begin{array}{c}17.9 \mathrm{Ma} \\
\text { (C5DN-1 base) }\end{array}$ \\
\hline 77.09 & & & & $18.1 \mathrm{Ma}$ & \\
\hline 77.1 & & & & & $\begin{array}{c}18.12 \mathrm{Ma} \\
\text { (C5DN-2 top) }\end{array}$ \\
\hline 77.5 & & & & & $\begin{array}{c}18.14 \mathrm{Ma} \\
\text { (C5DN-2 base) }\end{array}$ \\
\hline
\end{tabular}

\footnotetext{
${ }^{a}$ Data are presented in this paper.

${ }^{\mathrm{b}}$ Barron et al., this volume ( $\mathrm{D}=$ diatoms).

c Lazarus, in press $(\mathrm{R}=$ radiolarians).

d Barrera et al., this volume.

${ }^{\mathrm{e}}$ Keating, this volume.
} 